\title{
Effect of salicylic acid and yeast extract on curcuminoids biosynthesis gene expression and curcumin accumulation in cells of Curcuma zedoaria
}

\author{
Truong Thi Phuong Lan • Nguyen Duc Huy • Nguyen Ngoc Luong • Hoang Tan Quang • Trinh Huu Tan • \\ Le Thi Anh Thu $\cdot$ Nguyen Xuan Huy $\cdot$ Nguyen Hoang Loc
}

Received: 1 February 2019 / Revised: 27 March 2019 / Revised: 21 May 2019 / Accepted: 10 July 2019

(C) Korean Society for Plant Biotechnology

\begin{abstract}
The aim of this study is to evaluate the effect of yeast extract (YE) and salicylic acid (SA) on the expression of curcuminoid-biosynthesis genes (CzDCS and CURS1-3), and accumulation of curcumin in Curcuma zedoaria cell cultures. The results showed that, in cells treated with YE or SA, the expression levels of curcuminoid genes were 1.14to 3.64-fold higher than the control (untreated cells), in which the YE exhibited a stronger effect in comparison with SA. Curcumin accumulation also tended to be similar to gene expression, curcumin contents in YE- or SA-treated cells were 1.61- to 2.53-fold higher than the control. The SA treatment at the fifth day of culture stimulated the curcumin accumulation and expression in all four genes compared to that at the beginning. While the YE treatments gave different results, the $C z C U R S 1$ and $C z C U R S 3$ genes were expressed strongly in cells that were treated at the beginning. However, the $C z D C S$ and $C z C U R S 2$ genes showed the opposite expression pattern, they were activated strongly in the treatments at day five of the culture. However, the content of curcumin reached its maximum value on the fifth day of culture in all investigations.
\end{abstract}

\footnotetext{
N. N. Luong $\cdot$ L. T. A. Thu $\cdot$ N. H. Loc $(\bowtie)$

University of Sciences, Hue University, 77 Nguyen Hue St.,

Hue, Vietnam

e-mail: nhloc@hueuni.edu.vn

T. T. Phuong Lan

University of Medicine and Pharmacy, Hue University, 6 Ngo Quyen St., Hue, Vietnam

N. D. Huy $\cdot$ H. T. Quang · T. H. Tan

Institute of Biotechnology, Hue University, Phu Thuong, Phu

Vang, Thua Thien Hue, Vietnam

N. X. Huy

University of Education, Hue University, 34 Le Loi St., Hue, Vietnam
}

Keywords Curcuma zedoaria, curcuminoid genes, elicitor, salicylic acid, yeast extract

\section{Introduction}

Zedoary (Curcuma zedoaria Rosc.) is a perennial herb that belongs to the Zingiberaceae family found in tropical countries such as India, Japan, Thailand (Lobo et al. 2009), and Vietnam (Loi 2004). The rhizome of zedoary has been used in traditional and folk medicine for the treatment of menstrual disorders, dyspepsia, cough, vomiting, inflammations, hepatitis and diarrhoea (Azam et al. 2017).

Curcuminoid is a mixture of curcumin and its derivatives such as bisdemethoxycurcumin and demethoxycurcumin isolated from the rhizome of zedoary (Lobo et al. 2009) and other Curcuma species (Katsuyama et al. 2009; Lee et al. 2014; Gilani et al. 2015; Behar et al. 2016). Previous studies suggested that curcuminoids, especially curcumin, have valuable biological activities such as antioxidant, antitumor, anti-inflammatory, anti-acidogenic, radioprotective and neuroprotective properties (Hayakawa et al. 2011; Amalraj et al. 2017).

Genes involved in the pathway of curcuminoid metabolism in Curcuma longa included two type III polyketide synthase genes, DCS (diketide-CoA synthase) gene and CURS1 (curcumin synthase 1), CURS2 and CURS3 genes, and their expression levels were reported by Katsuyama et al. (2009a, b). Brand et al. (2006) characterized another type III polyketide synthase gene, chalcone synthase $(C H S)$ gene, in Wachendorfia thyrsiflora. This gene is also involved in the biosynthesis of curcuminoids. Behar et al. (2016) analysed expression of genes which participate in curcuminoid biosynthesis in C. caesia including DCS, CURS, CURS2, CURS3 and CHS1. All the genes exhibited a higher expression level in the rhizome compared to leaves. Sandeep et al. 
(2017) evaluated expression of CURS gene in C. longa at different experimental areas and harvesting phases towards cultivation for high curcumin yield. In a recent study, we also found four similar curcuminoid genes (named $C z D C S$, $C z C U R S 1, C z C U R S 2$ and $C z C U R S 3$ with the corresponding accession numbers are MF663785, MF402846, MF402847, and MF987835) in zedoary (C. zedoaria, $C z$ ) and their expression in rhizome and callus (Lan et al. 2018).

Elicitors are the chemical compounds which have been used to modify the pathway of secondary metabolism in order to enhance of the biosynthesis of pharmaceutically significant metabolites or phytopharmaceuticals in plant cell cultures (Jeong and Park 2005; Namdeo 2007). Accordings to Abraham et al. (2011), yeast extract (YE) has been applied in plant tissue culture due to its ability to stimulate the defence mechanism, which leads to increase production of secondary metabolites. Salicylic acid (SA) is recognized as one of important signals in plant defense response and are also widely used for secondary metabolite production in plant cell cultures (Badrhadad et al. 2013). The present work therefore investigated the effect of elicitors such as YE and SA on activation of curcuminoid genes in callus cells of zedoary. Our results provided the first evidence for role of SA and YE as positive regulators of elicitorinduced gene expression in this plant species.

\section{Materials and Methods}

\section{Cell culture and elicitation}

Buds $(1.5 \mathrm{~cm})$ from the rhizome of zedoary (C. zedoaria Roscoe) distributed in Thua Thien Hue province (Vietnam) were sterilized and cultured on the MS (Murashige and Skoog, 1962) medium including $2 \%(w / v)$ sucrose and $0.8 \%(w / v)$ agar, supplemented with $20 \%(v / v) \mathrm{CW}$ (coconut water), $3 \mathrm{mg} / \mathrm{L}$ BAP (benzylaminopurine), $0.5 \mathrm{mg} / \mathrm{L}$ IBA (indolebutyric acid) and $1.5 \mathrm{mg} / \mathrm{L} \mathrm{AgNO}_{3}$ for shoot multiplication. Single shoots $(3 \sim 4 \mathrm{~cm})$ were isolated from the shoot clusters to develop into plantlets on the MS medium supplemented with $20 \%(v / v) \mathrm{CW}, 2 \mathrm{mg} / \mathrm{L}$ NAA (naphthaleneacetic acid) and $1.5 \mathrm{mg} / \mathrm{L} \mathrm{AgNO}_{3}$. Leaf-bases $(0.5 \times 0.5$ $\mathrm{cm}$ ) of plantlet were cultured on the MS medium supplemented with $3 \mathrm{mg} / \mathrm{L}$ 2,4-D (2,4-dichlorophenoxyacetic acid) and $3 \mathrm{mg} / \mathrm{L}$ BAP for callus induction, callus was then subcultured on the MS medium with $1 \mathrm{mg} / \mathrm{L}$ 2,4-D and $1 \mathrm{mg} / \mathrm{L}$ kinetin for proliferation.

Cell culture of zedoary was established by agitating $3 \mathrm{~g}$ of callus in $250 \mathrm{~mL}$ Erlenmeyer flask containing $50 \mathrm{~mL}$

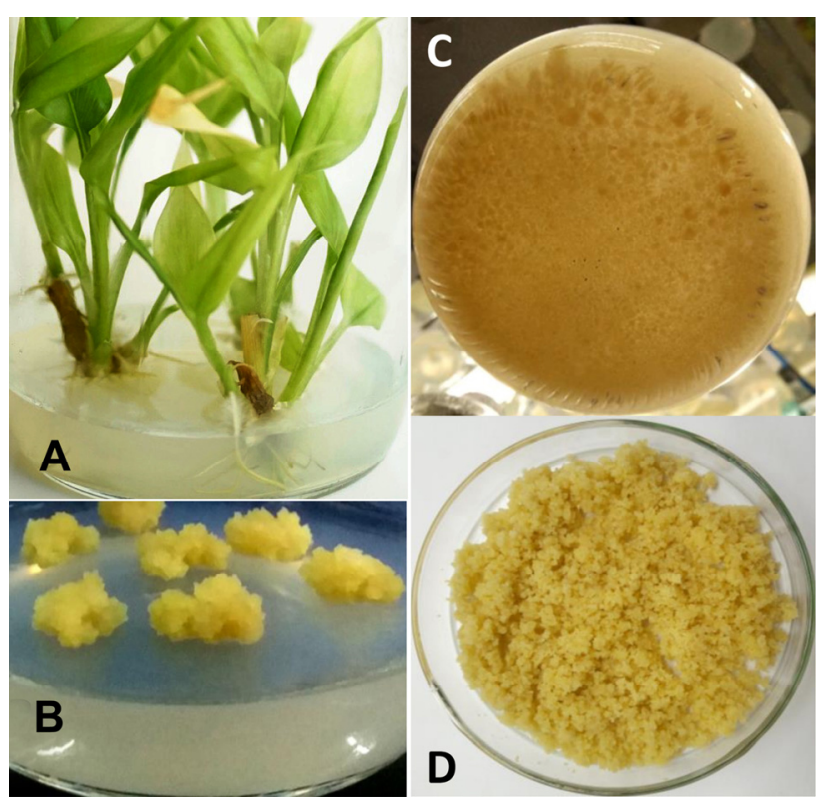

Fig. 1 In vitro cultures of zedoary. A: plantlet, B: callus, C: suspension cells, D: fresh cell biomass.

of liquid MS medium including 2\% (v/v) of sucrose, supplemented with $3 \mathrm{mg} / \mathrm{L}$ of 2,4-D and $3 \mathrm{mg} / \mathrm{L}$ of BAP until a suspension of free cells formed. The suspension was then cultured on a rotary shaker at a speed of $150 \mathrm{rpm}$ for 12 days to produce biomass (Fig. 1).

Three gram of 12 day old cells (at near the end of the growth phase) were subcultured on the same medium but supplemented with $100 \mu \mathrm{M}$ of SA or $1 \mathrm{~g} / \mathrm{L}$ of $\mathrm{YE}$ at various culture times to investigate changes in expression of curcuminoid genes related to curcumin biosynthesis.

Salicylic acid solution was prepared as a stock solution by completely dissolved $0.138 \mathrm{~g}$ SA into $5 \mathrm{~mL}$ of $100 \%$ ethanol. Five milliliters of water was added to solution to a final concentration of $100 \mathrm{mM}$ and filtrated through Millipore $^{\mathrm{TM}}$ Membrane Filter $(0.22 \mu \mathrm{m}$ pore size). After then, $50 \mu \mathrm{L}$ of stock solution were added to $50 \mathrm{~mL}$ liquid medium to a concentration of $100 \mu \mathrm{M}$. Yeast extract was directly added to medium to a concentration of $1 \mathrm{~g} / \mathrm{L}$ before autoclaving.

The cell culture was incubated at $25 \pm 2^{\circ} \mathrm{C}$ with a photoperiod of $10 \mathrm{~h}$ daylight at an light intensity of approximately $6.75 \mu \mathrm{mol} / \mathrm{s} / \mathrm{m}^{2}$.

Gene expression

Expression level of curcuminoid genes (CzDCS, CzCURS1, $C z C U R S 2$ and $C z C U R S 3)$ in various zedoary samples was analysed by semi-quantitative RT-PCR (reverse transcriptionpolymerase chain reaction) with the primers designed 
Table 1 Primers used for RT-PCR amplification of the specific regions of curcuminoid-biosynthesis genes in zedoary

\begin{tabular}{|c|c|c|c|c|}
\hline Gene & Primer name & Primer sequence $\left(5^{\prime}-3^{\prime}\right)$ & $\begin{array}{l}\text { Amplified length } \\
\text { (bp) }\end{array}$ & $\begin{array}{c}\text { Annealing temperature } \\
\left({ }^{\circ} \mathrm{C}\right)\end{array}$ \\
\hline \multirow{2}{*}{$C z D C S$} & ID-F & TGCTCCGAGGTCACCGTGC & \multirow{2}{*}{272} & \multirow{2}{*}{55} \\
\hline & ID-R & GGTCAGCCCAATTTCGCGG & & \\
\hline \multirow{2}{*}{$C z C U R S 1$} & $\mathrm{IC} 1-\mathrm{F}$ & CCGCTGGAAGGAATTGAAAAA & \multirow{2}{*}{286} & \multirow{2}{*}{55} \\
\hline & IC1-R & GAGCTTGTCCGGGCTCAGCTG & & \\
\hline \multirow{2}{*}{$\mathrm{Cz} C U R S 2$} & IC2-F & CCACCTCCGCGAGGTGGGGCT & \multirow{2}{*}{211} & \multirow{2}{*}{55} \\
\hline & IC2-R & GCGGTGGCCAGCTTGCTCTGT & & \\
\hline \multirow{2}{*}{$C z C U R S 3$} & IC3-F & CACCTGAGGGAAATCGGCTGG & \multirow{2}{*}{202} & \multirow{2}{*}{50} \\
\hline & IC3-R & GCGAGCTTCCCCTGTTCCAGC & & \\
\hline
\end{tabular}

\begin{tabular}{|c|c|c|}
\hline CzDCS & ССTCGCGGAGAACAACCGCGGCGCGCGGGTGCTCGCCGTCTGCTCCGAGGTCACCGTGCT & 711 \\
\hline CzCURS1 & ССTCGCCGAGAACAACAGGGGCGCGCGCGTGCTGGTGGTCGCCTGCGAGATCACCGTGCT & 657 \\
\hline CzCURS2 & САTCGCCGAGAACAACCGCTCCGCTCGCGTCCTCGTCGTCGCCTGCGAGATCACCGTGCT & 705 \\
\hline \multirow[t]{2}{*}{ CzCURS3 } & ССTCGCGGAGAACAACCGGGGCGCGCGCGTCCTGGCCGTCTCCTGCGAAATCACCGTGTT & 679 \\
\hline & 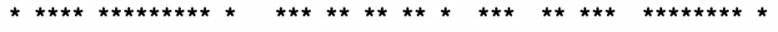 & \\
\hline CzDCS & СTCCTACCGCGGCCCCCACCCCGCCCACATCGAGAGCCTCTTCGTCCAAGCTCTGTTTGG & 771 \\
\hline CzCURS1 & СAGCTTCCGCGGCCCGAACGAGGGCGACTTCGAGGCGCTCGCGGGGCAGGCCGGCTTCGG & 717 \\
\hline CzCURS2 & CAGCTTCCGCGGCCCGGACGAGCGCGACTTCCAGGCGCTGGCCGGCCAGGCCGGCTTCGG & 765 \\
\hline \multirow[t]{2}{*}{ CzCURS3 } & САGCTTCCGCGGTCCCGACGCGGGCGACTTCGAGGCCCTCGCGTGTCAGGCCGGCTTCGG & 739 \\
\hline & 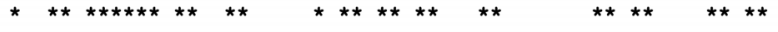 & \\
\hline CzDCS & CGACGGCGCTGCCGCGCTCGTGGTCGGGTCCGACCCCGTCGATGGCGTCGAGCGCCCCAT & 831 \\
\hline CzCURS1 & CGACGGCGCGGGGGCCGTCGTCGTCGGGGCCGACCCGCTGGAAGGAATTGAAAAACCCAT & 777 \\
\hline CzCURS2 & GGACGGCGCCGGCGCGATGATCGTCGGGGCCGACCCCGTCCTCGGCGTCGAGCGGCCGCT & 825 \\
\hline \multirow{2}{*}{ CzCURS3 } & CGACGGTGCCGCTGCCGTCGTCGTCGGGGCCGACCCCCTCCCGGGCGTCGAGAGGCCCAT & 799 \\
\hline & 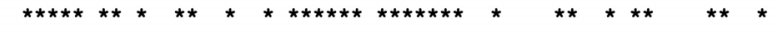 & \\
\hline CzDCS & СTTCGAAATCGCCTCGGCATCCCAAGTAATCGCTGCTCCAGTCGAAATTAACCAAAATTC & 891 \\
\hline CzCURS1 & CTACGAGATCGC- & 789 \\
\hline CzCURS2 & 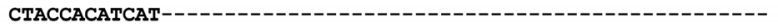 & 837 \\
\hline \multirow[t]{2}{*}{ CzCURS3 } & СTACGAGATCGC- & 811 \\
\hline & 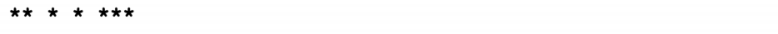 & \\
\hline CzDCS & GATCTTTTGATATCGAACGAACTTTAAAAATCAAATCTTTGGCACCGCAGGTGATGCTTC & 951 \\
\hline CzCURS1 & ---1-1-1, & 812 \\
\hline CzCURS2 & - GTCGGCGACTCAGACGACGGTGC & 860 \\
\hline \multirow{2}{*}{ CzCURS3 } & 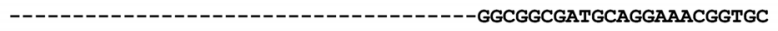 & 834 \\
\hline & *** $\quad * * * \quad * * *$ & \\
\hline CzDCS & CGGAGAGCGAAGAGGCGGTAGGCGGCCACCTCCGCGAAATTGGGCTGACCTTCCACCTCA & 1011 \\
\hline CzCURS1 & CGGAGAGCCAGGGGGCGGTGGGCGGCCACCTGCGGGCGTTCGGCTGGACGTTCTACTTCC & 872 \\
\hline CzCURS2 & CGGAGAGCGAGAAGGCGGTGGGGGGCCACCTCCGCGAGGTGGGGCTEACCTTCCACTTCT & 920 \\
\hline \multirow[t]{2}{*}{ CzCURS3 } & CGGAGAGCGAGAGGGCGGTGGGGGGCCACCTGAGGGAAATCGGCTGGACCTTCCACTTCT & 894 \\
\hline & 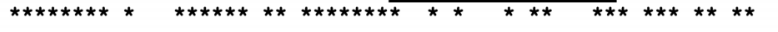 & \\
\hline CzDCS & AGAGCCAGCTTCCGTCGATCATCGCGAGCAACATCGAGCAGAGCCTEACGACTGCGTGCT & 1071 \\
\hline CzCURS1 & TGAACCAGCTGCCGGCGATCATCGCCGACAACCTCGGGAGGAGCCTGGAGCGGGCGTTGG & 932 \\
\hline CzCURS2 & TCAACCAGCTGCCGGCGATCATCGCCGACAACGTGGGGAACAGCCTGGCGGAGGCGTTCG & 980 \\
\hline \multirow[t]{2}{*}{ CzCURS3 } & TCAACCAGCTGCCGAAGCTGATCGCGGAAAACATCGAGGGCAGCCTGGCGCGGGCGTTCA & 954 \\
\hline & 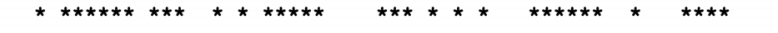 & \\
\hline CzDCS & CGCCGCTGGGGCTGTCGGACTGGAACCAGCTGTTCTGGGCGGTTCACCCCGGCGGCCGAG & 1131 \\
\hline CzCURS1 & CGCCGCTGGGGGTGACGGAGTGGAACGACGTCTTCTGGGTGGCGCACCCGGGCAACTGGG & 992 \\
\hline CzCURS2 & AACCGATCGGGATCAAGGACTGGAACAACATCTTCTGGGTGGCGCACCCGGGCAACTGGG & 1040 \\
\hline \multirow[t]{2}{*}{ CzCURS3 } & AGCCGCTGGGGATCAGCGAGTGGAACGACGTGTTCTGGGTGGCGCACCCGGGGAATTGGG & 1014 \\
\hline & 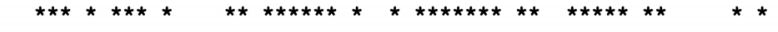 & \\
\hline & GATCCTGGACCAGGTGGAGGCGCGGCTCGGACTGGAGAAGGACCGGCTCGCCGCGACGC & 1191 \\
\hline URS1 & CCATCATGGACGCCATCGAAGCCAAGCTGCAGCTGAGCCCGGACAAGCTCAGCACCGCCC & 1052 \\
\hline CzCURS2 & ССATCATGGACGCCATCGAGACCAAGCTGGGCCTGGAACAGAGCAAGCTGGCCACCGCAC & 1100 \\
\hline \multirow[t]{2}{*}{ CzCURS3 } & GCATCATGGACGCCATCGAGACCAAGCTGGGGCTGGAACAGGGGAAGCTCGCCACGGCGC & 1074 \\
\hline & $* * * * * * * \quad * * * \quad * \quad * * * \quad * * * \quad * \quad * * * \quad * * * *$ & \\
\hline & GCACGTACTCAGCGAGTACGGCAACATGCAGAGCGCCACGGTGCTGTTCATCCTGGACG & \\
\hline & CCACGTCTTCACAGAGTACGGCAACATGCAGAGCGCCACCGTGTACTTCGTGATGGATG & 1112 \\
\hline CzCURS2 & GCCACGTCTTCTCCGAGTTCGGCAACATGCAGAGCGCCACCGTCTACTTCGTGATGGACG & 1160 \\
\hline \multirow[t]{2}{*}{ CzCURs3 } & GCCACGTCTTCAGCGAGTACGGAAACATGCAGAGCGCCACCGTGTACTTCGTGATGGACG & 1134 \\
\hline & 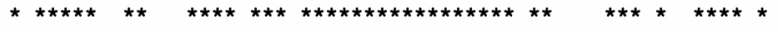 & \\
\hline CzDCS & AGATGCGGAACCGCTCGGCTGCGGAGGGCCACGCCACCACCGGCGAGGGGCTCGACTGGG & 1311 \\
\hline & AGCTGAGGAAGCGGTCGGCGGTGGAGGGGCGGAGCACCACCGGAGACGGCTTGCAGTGGG & 1172 \\
\hline CzCURS2 & AGCTCAGGAAACGGTCGGCGGCGGAGAACCGGGCGACCACCGGCGACGGGCTCCGGTGGG & 1220 \\
\hline \multirow[t]{2}{*}{ CzCURS3 } & AGGTGAGGAAGCGGTCGGCGGCGGAGGGGCGGGCCACCACCGGCGAAGGCCTGGAGTGGG & 1194 \\
\hline & 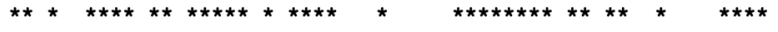 & \\
\hline
\end{tabular}

Fig. 2 Alignment of partial sequences of curcuminoid genes. Black boxes are regions used to design primers for RT-PCR

based on their specific regions (Table 1 and Fig. 2).

Fresh samples of $200 \mathrm{mg}$ were ground to a fine powder by using liquid nitrogen. Total RNAs of samples were extracted by InviTrap Spin Plant RNA Mini Kit (STRATEC Biomedical, Germany) and 1st cDNA strand was synthesized by First Strand cDNA Synthesis Kit (Thermo Scientific), 
both are under the manufacturer's instructions.

PCR amplification was performed as follows: $2 \mu \mathrm{L}$ cDNA, 10 pmol each primer, $6 \mu \mathrm{L} 2 \times$ GoTaq ${ }^{\circledR}$ Green Master Mix (Promega), and $\mathrm{ddH}_{2} \mathrm{O}$ in a final volume of $12 \mu \mathrm{L}$. The reaction was performed in PCR machine (Veriti 96 Well Thermal Cycler, ABI) with a template denaturation of $95^{\circ} \mathrm{C}$ for $2 \mathrm{~min}$; followed by $20 \sim 30$ cycles of $95^{\circ} \mathrm{C}$ for $30 \mathrm{~s}$, $50-55^{\circ} \mathrm{C}$ for $30 \mathrm{~s}$ (Table 1 ), and $72^{\circ} \mathrm{C}$ for $30 \mathrm{~s}$; and a final extension of $72^{\circ} \mathrm{C}$ for $10 \mathrm{~min}$.

Three microliters of each PCR product was used for electrophoresis on $1 \%(w / v)$ agarose gel at $70 \mathrm{~V}$ and intensities of DNA bands were calculated using ImageJ program (version: $\mathrm{k} 1.45$ ).

High performance liquid chromatography

Cell biomass was dried at $50^{\circ} \mathrm{C}$ to a constant weight, then ground into a fine powder. Two grams of powder was soaked in $20 \mathrm{~mL}$ of $70 \%(\mathrm{v} / \mathrm{v})$ ethanol for $30 \mathrm{~min}$ at $30^{\circ} \mathrm{C}$ and then treated by ultrasound on $\mathrm{T} 700 / \mathrm{H}$ machine (Elma, Germany). The sample was filtered with Whatman filter paper (No. 1), the residue was extracted again with the same solvent for several times until the solvent layer became colorless. After filtration with Whatman paper, the filtrates were mixed and the solvent was removed at $70^{\circ} \mathrm{C}$ by using a vacuum rotary concentrator (Heidolph, Germany). The concentrate was dissolved by $70 \%(v / v)$ ethanol to 10 $\mathrm{mL}$ (curcumin extract) and filtered through Minisart 0.25 $\mu \mathrm{m}$ membrane (Sartorius, Germany), the extract was then diluted two times for subjecting HPLC at ambient temperature by using a Hypersil ${ }^{\mathrm{TM}}$ MOS C8 LC Column $(5 \mu \mathrm{m}$, $4.6 \times 150 \mathrm{~mm})$.

HPLC condition was as follows, flow rate: $1 \mathrm{~mL} / \mathrm{min}$, run time: $10 \mathrm{~min}$, detector wavelength: $420 \mathrm{~nm}$, stationary phase: silica gel (reverse phase) and mobile phase: acetonitrile/2\% acetic acid $(35 / 65, v / v)$. Ten microliters of curcumin extract were injected the chromatographic column using Hamilton syringe. HPLC analysis was performed on a Spectra System (Thermo Electron).

All solvents were of analytical grade and were purchased from Sigma and Merck \& Co., Inc. The standard curve of curcumin (Sigma) in ethanol at different concentrations from $1 \sim 20 \mu \mathrm{g} / \mathrm{mL}$ is used for determination of the curcumin in the extract. Curcumin content of the extract is calculated based on the peak area with retention time corresponding to the standard curcumin.

Statistical analysis

The experiments were done in triplicate, $n=10$ for each replication in in vitro culture experiments. The data were analyzed as means followed by one-way ANOVA (Duncan's test, $p<0.05)$.

\section{Results and Discussion}

\section{Growth of zedoary cells}

Zedoary cells in shaking culture were harvested every two days to determine their biomass propagation. Figure 3 shows the growth increased from day 2 to day 14 and then decreased at days 16 and 18. Maximum biomass of approximately $8.3 \mathrm{~g}$ of fresh weight (per $50 \mathrm{~mL}$ of cell culture volume) is equivalent to $0.73 \mathrm{~g}$ of dry weight. Twelve day-old cells were subcultured in the fresh medium for elicitation, cell biomass was then harvested at 14th day of subculture to evaluate expression level of curcuminoidbiosynthesis genes and their curcumin accumulation.

Table 2 shows the growth of $C$. zedoary cells in all treatments was inhibited significantly, highest biomass per $50 \mathrm{~mL}$ of cell culture volume is only approximately 5.2 $\mathrm{g}$ fresh weight $(0.5 \mathrm{~g}$ dry weight) versus about $8.3 \mathrm{~g}$ fresh weight ( $0.73 \mathrm{~g}$ dry weight) of the control. In general, the effect of exogenous elicitors on in vitro growth depends on the plant species, developmental stage, and the elicitor concentration. Negative effects of SA and YE on the growth have also been observed in different in vitro culture systems as in Sophora flavescens (Yamamoto et al. 1995), Dendrobium huoshanense (Wang et al. 2009), Salvia miltiorrhiza (Zhao et al. 2010), a mutant of Lotus japonicus, named Ljsym4-2 (Bastianelli et al. 2010), Centella asiatica (Loc et al. 2017).

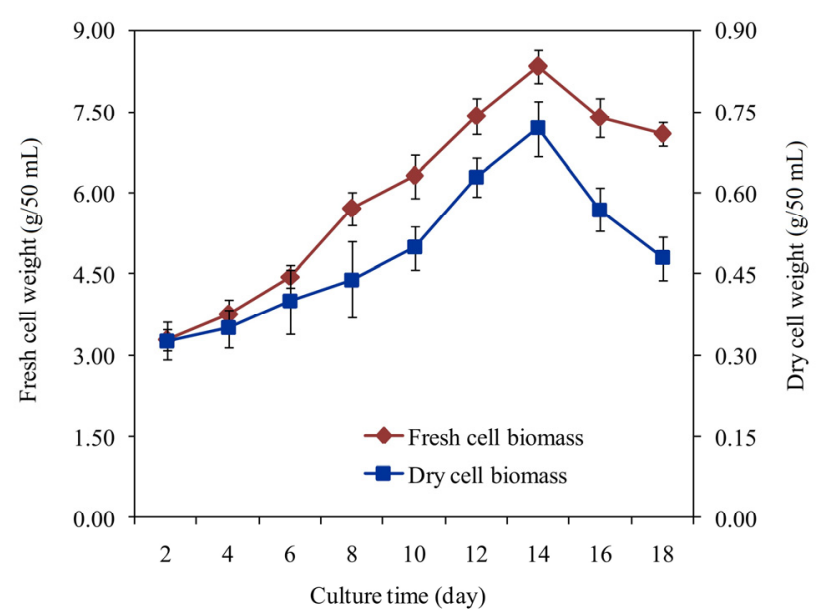

Fig. 3 Time course of $C$. zedoaria cell growth. Data are means \pm $\mathrm{SE}$ of three biological replicates 
Table 2 Effect of elicitors on the growth and curcumin accumulation of zedoary cells

\begin{tabular}{|c|c|c|c|}
\hline \multirow{2}{*}{ Elicitation } & \multicolumn{2}{|c|}{ Cell growth } & \multirow{2}{*}{ Curcumin $(\mathrm{mg} / \mathrm{g})$} \\
\hline & Fresh weight $(\mathrm{g} / 50 \mathrm{~mL})$ & Dry weight $(\mathrm{g} / 50 \mathrm{~mL})$ & \\
\hline $\mathrm{YE}^{(1)}$ & $5.26^{\mathrm{b}}$ & $0.49^{\mathrm{b}}$ & $0.92^{\mathrm{d}}$ \\
\hline $\mathrm{YE}^{(2)}$ & $4.88^{\mathrm{c}}$ & $0.42^{\mathrm{c}}$ & $1.44^{\mathrm{a}}$ \\
\hline $\mathrm{SA}^{(1)}$ & $3.45^{\mathrm{d}}$ & $0.31^{\mathrm{d}}$ & $1.14^{\mathrm{c}}$ \\
\hline $\mathrm{SA}^{(2)}$ & $3.16^{\mathrm{d}}$ & $0.30^{\mathrm{d}}$ & $1.32^{\mathrm{b}}$ \\
\hline Non-elicited cells & $8.26^{\mathrm{a}}$ & $0.73^{\mathrm{a}}$ & $0.57^{\mathrm{f}}$ \\
\hline 10 month-old rhizome & - & - & $0.78^{\mathrm{e}}$ \\
\hline
\end{tabular}

Elicitors were added in the medium at the beginning of culture (1) and after 5 days of culture (2). Different letters in a column indicate significantly different means (Duncan's test, $p<0.05$ ).

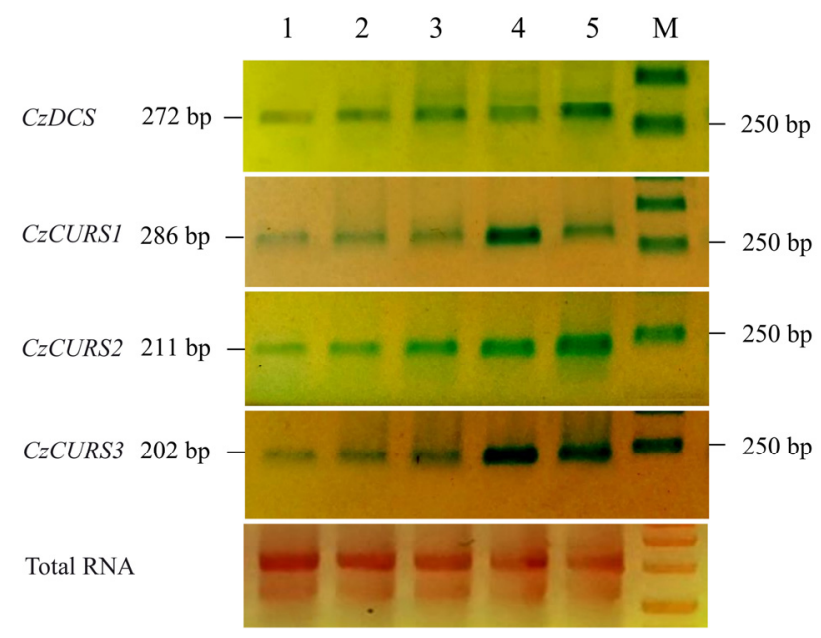

Fig. 4 RT-PCR amplification of the specific regions of curcuminoid genes in C. zedoary. 1: control (untreated cells), 2 and 4: cells treated with salicylic acid and yeast extracts at the beginning of culture, respectively. 3 and 5: cells treated with salicylic acid and yeast extracts after five days of culture, respectively. M: DNA size marker (1 kb DNA Ladder)

Effect of elicitors on expression of curcuminoid-biosynthesis genes

In the present work, $1 \mathrm{~g} / \mathrm{L}$ YE or $100 \mu \mathrm{M}$ SA was added to the medium at two time-points, at the beginning and the 5th day of culture. The other concentrations and treatment time points of SA and YE were also investigated but curcumin accumulation found in cells is insignificant (data not shown).

Although semi-quantitative RT-PCR will not produce as good quality results as those of quantitative PCR, Lenka et al (2012) and Dewanjee et al (2014) argued that it is still sufficient for differential gene expression analysis. Our results of semi-quantitative RT-PCR in 25 cycles exhibited that expressions of curcuminoid genes in treated cells are higher than that of untreated cells (Fig. 4). Expression levels of genes were evaluated through the intensities of DNA

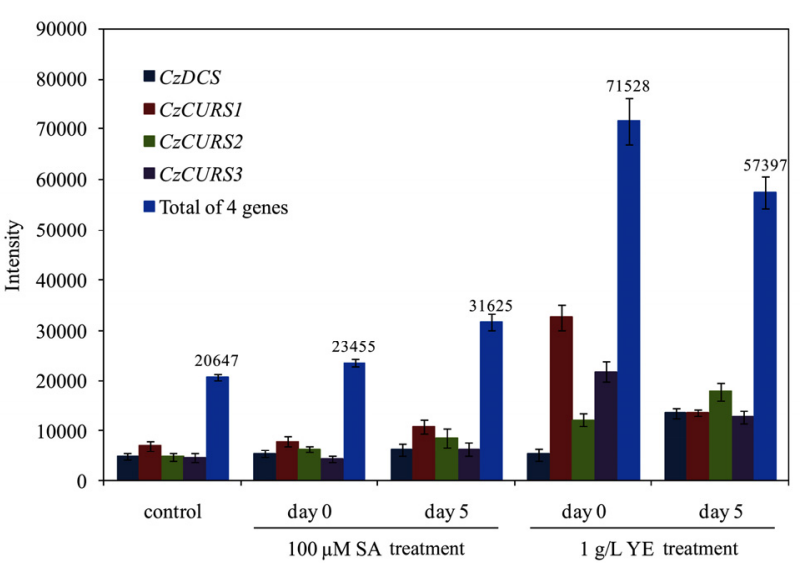

Fig. 5 Intensities of DNA bands from semi-quantitative RT-PCR of the specific regions of curcuminoid-biosynthesis genes. 0 and 5: elicitors were added in the medium at the beginning and after five days of culture, respectively. Data are means $\pm \mathrm{SE}$ of three biological replicates

bands in agarose gel showed that they are 1.14 to 3.64-fold higher than the control (Fig. 5). Expression of curcuminoid genes in treated and untreated cells was not different significantly in 20 and 30 cycles of amplification (data not shown).

In general, YE showed a higher elicitation effect compare to SA, the total intensity of DNA bands reached a maximum value of 71528 versus 23455 (approx. 3-fold) from treatments at day 0 and 57397 versus 31625 (approx. 1.8-fold) from treatments at day 5. Data in Figure 5 also indicated that the SA treatment at 5th day of cell culture stimulated the stronger expression in all four genes, $C z D C S$ and $C z C U R S$ $1 \sim 3$, compared to that at the beginning. While YE treatments gave different results, the $C z C U R S 1$ and $C z C U R S 3$ genes were expressed strongly in cells which treated at the begining, but the $C z D C S$ and $C z C U R S 2$ genes showed the opposite effect, they were activated strongly in the treatments at day 5 of the culture. Overall, the YE treatment at the beginning resulted in the total intensity of all four genes 
is about 1.3-fold higher than that at 5th day of culture.

One issue with our approach for gene expression analysis was that a proper internal control such as chalcone synthase is not accessible since the such gene sequences in $C$. zedoaria are not yet made available on Genbank. The scarcity of sequence information of $C$. zedoaria also makes it impossible for including pathogenesis related genes in our elicitation experiments to validate that changes in genes expressions were due to the effects of used elicitors. To ensure that the differences observed in gene expression levels are genuine, we included total RNA in our analysis to show that equal amounts of RNA, as well as cDNA were used for the semi-quantitative RT-PCR.

Several previous studies also found an enhanced expression of elicitor-induced genes in plant cell cultures such as OsWRKY53 gene in rice cells treated with fungal cerebroside (Chujo et al. 2007), defense genes in parsley (Petroselinum crispum) cells treated with methyl jasmonate (Ellard-Ivey and Douglas, 1996), or defense genes in cells of two grapevine species (Vitis rupestris and $V$. vinifera) treated with Harpin (Qiao et al. 2010). Especially, Park et al. (2016) showed that YE and silver nitrate can induce the higher expression of phenylpropanoid biosynthesis genes and enhance accumulation of rosmarinic acid in Agastache rugosa cell culture. In another report, we determined the influence of SA on expression of genes involved in the pathway of phytosterol and triterpene biosynthesis in in vitro centella (Centella asiatica) cells (Loc et al. 2016).

The effect of the exogenous SA and YE on the gene expression level depends on the plant species, developmental stage, and elicitor concentration. Although, both YE and SA trigger the accumulation of endogenous jasmonic acid that up-regulates the expression of key genes involved in secondary metabolism of plants (Rahimi et al. 2014). Our results indicated that in comparison to abiotic elicitor is SA, YE biotic elicitor is more effective in enhancing the expression of curcuminoid-biosynthesis genes.

\section{Effect of elicitors on curcumin production}

Curcumin is one of three components of curcuminoid group found in Curcuma species including demethoxycurcumin and bisdemethoxycurcumin. In the curcuminoid pathway in C. longa which started by phenylalanine, CzDCS metabolizes feruloyl-CoA from p-coumaroyl-CoA into feruloyldiketide-CoA, then CzCURS1-3 will convert feruloyldiketideCoA into curcumin. Besides, CzCURS3 can produce demethoxylcurcumin from feruloyldiketide-CoA. Simultaneously, CzDCS also participate the transformation of p-coumaroyl-
CoA into p-coumaroyldiketide-CoA, and then CzCURS1-3 or single CzCURS3 will metabolize this compound into demethoxycurcumin and bisdemethoxycurcumin (Katsuyama et al. 2009).

The correlation between expression of curcuminoid genes and curcumin biosynthesis in C. zedoaria cells was found through RT-PCR amplification and HPLC analysis. The effect of YE treatment on curcumin production is higher than that of SA and the control. Curcumin content from cells treated with SA and YE at 5th day of culture is approximate from 1.2- to 1.6-fold higher than that treated at the beginning, $1.32 \mathrm{vs} 1.14 \mathrm{mg} / \mathrm{g}$ and $1.44 \mathrm{vs} 0.92 \mathrm{mg} / \mathrm{g}$ (Table 2). In the YE treatment, the results on the curcumin contents did not appear to correspond to expression levels of curcuminoid genes. Total intensity of PCR products obtained from treated cells at the beginning of culture is stronger than that at 5th day (Fig. 5). The cause may be the curcuminoid genes contributed to not only in the biosynthesis of curcumin but also demethoxycurcumin and bisdemethoxycurcumin.

Generally, our results are also similar to several previous studies. The accumulation of major products of secondary metabolism in plant cell cultures has been correlated with the expression of coordinate genes under the effect of suitable elicitors. For example, activation of expression of phenylpropanoid genes and accumulation of furanocoumarin in Petroselinum crispum cells treated with methyl jasmonate (Ellard-Ivey and Douglas, 1996) or rosmarinic acid in Agastache rugosa cells treated with YE and silver nitrate (Park et al. 2016).

In conclusion, expression levels of curcuminoid-biosynthesis genes in YE- and SA-treated C. zedoaria cells were 1.14 to 3.64-fold higher than those in untreated cells, in which YE at $1 \mathrm{~g} / \mathrm{L}$ showed a higher stimulation effect for gene expression than SA at $100 \mu \mathrm{M}, 1.8$ - to 3-fold after 9 and 14 days of treatment, respectively. Curcumin accumulation in treated cells was 1.61- to 2.53-fold higher than the control.

\section{Acknowledgments}

This work was funded by Grant from Hue University, Vietnam (Code number: DHH 2016-04-56).

\section{Conflict of interest}

We declare that there is no conflict of interest regarding the publication of this article. 


\section{References}

Abraham F, Bhatt A, Keng CL, Indrayanto G, Sulaiman SF (2011) Effect of yeast extract and chitosan on shoot proliferation, morphology and antioxidant activity of Curcuma mangga in vitro plantlets. African Journal of Biotechnology 10:7787-7795

Amalraj A, Pius A, Gopi S, Gopi S (2017) Biological activities of curcuminoids, other biomolecules from turmeric and their derivatives - A review. J Tradit Complement Med 7:205-233

Azam MG, Noman MS, Pavel MAM (2017) Evaluation of anti-diarrhoeal activity of Curcuma zedoaria rhizome. J Pharmacogn Phytochem 6:171-173

Badrhadad A, Piri K, Ghiasvand T (2013) Increasing of alphatocopherol in cell suspension cultures Elaeagnus angustifolia L. Intl J Agri Crop Sci 5:1328-1331

Bastianelli F, Costa A, Vescovi M, D’Apuzzo E, Zottini M, Chiurazzi M, Lo Schiavo F (2010) Salicylic acid differentially affects suspension cell cultures of Lotus japonicus and one of its non-symbiotic mutants. Plant Mol Biol 72:469-483

Behar N, Tiwari KL, Jadhav SK (2016) Semi-quantitative expression studies of genes involved in biosynthesis of curcuminoid in Curcuma caesia Roxb. Indian J Biotechnol 15:491-494

Brand S, Hölscher D, Schierhorn A, Svatos A, Schröder J, Schneider B (2006) A type III polyketide synthase from Wachendorfia thyrsiflora and its role in diarylheptanoid and phenylphenalenone biosynthesis. Planta 224:413-428

Chujo T, Takai R, Akimoto-Tomiyama C, Ando S, Minami E, Nagamura Y, Kaku H, Shibuya N, Yasuda M, Nakashita H, Umemura K, Okada A, Okada K, Nojiri H, Yamane H (2007) Involvement of the elicitor-induced gene OsWRKY53 in the expression of defense-related genes in rice. Biochim Biophys Acta 1769:497-505

Dewanjee S, Gangopadhyay M, Das U, Sahu R, Samanta A, Banerjee P (2014) Signal transducer and oxidative stress mediated modulation of phenylpropanoid pathway to enhance rosmarinic acid biosynthesis in fungi elicited whole plant culture of Solenostemon scutellarioides. Enzyme Microb Technol 66:1-9

Ellard-Ivey M, Douglas CJ (1996) Role of jasmonates in the elicitorand wound-inducible expression of defense genes in parsley and transgenic tobacco. Plant Physiol 112:183-192

Gilani SA, Kikuchi A, Shimazaki T, Wicaksana N, Wunna, Watanabe KN (2015) Molecular genetic diversity of curcuminoid genes in Curcuma amada: Curcuminoid variation, consideration on species boundary and polyploidy. Biochem Syst Ecol 61: 186-195

Hayakawa H, Minaniya Y, Ito K, Yamamoto Y, Fukuda T (2011) Difference of curcumin content in Curcuma longa L. (Zingiberaceae) caused by hybridization with other Curcuma species. Am J Plant Sci 2:111-119

Jeong GT, Park DH (2005) Enhancement of growth and secondary metabolite biosynthesis: Effect of elicitors derived from plants and insects. Biotechnol Bioprocess Eng 10:73-77

Katsuyama Y, Kita T, Horinouchi S (2009a) Identification and characterization of multiple curcumin synthases from the herb Curcuma longa. FEBS Lett 583:2799-2803
Katsuyama Y, Kita T, Funa N, Horinouchi S (2009b) Curcuminoid biosynthesis by two type III polyketide synthases in the herb Curcuma longa. J Biol Chem 284:11160-11170

Lan TTP, Huy ND, Luong NN, Nghi NV, Tan TH, Quan LV, Loc $\mathrm{NH}$ (2018) Identification and characterization of genes in the curcuminoid pathway of Curcuma zedoaria Roscoe. Curr Pharm Biotechnol 19:839-846

Lee J, Jung Y, Shin JH, Kim HK, Moon BC, Ryu DH, Hwang GS (2014) Secondary metabolite profiling of Curcuma species grown at different locations using GC/TOF and UPLC/Q-TOF MS. Molecules 19:9535-9551

Lenka SK, Boutaoui N, Paulose B, Vongpaseuth K, Normanly J, Roberts SC, Walker EL (2012) Identification and expression analysis of methyl jasmonate responsive ESTs in paclitaxel producing Taxus cuspidate suspension culture cells. BMC Genomics 13:148

Lobo R, Prabhu KS, Shirwaikar A and Shirwaikar A (2009) Curcuma zedoaria Rosc. (white turmeric): a review of its chemical, pharmacological and ethnomedicinal properties. J Pharm Pharmacol 61:13-21

Loc NH, Giang NT, Huy ND (2016) Effect of salicylic acid on expression level of genes related with isoprenoid pathway in centella (Centella asiatica (L.) Urban) cells. 3 Biotech 6:86

Loc NH, Giang NT, Huy ND, Lan TTP (2017) Accumulation of madecassoside - a major component of centelloside - in centella (Centella asiatica (L.) Urban) cells elicited by salicylic acid. Period Biol 119:81-85

Loi DT (2004) Medicinal plants and Vietnamese traditional medicines. Medical Publishing House, Hanoi, Vietnam.

Murashige T, Skoog F (1962) A revised medium for rapid growth and bioassays with tobacco tissue cultures. Physiol Plant $15: 473-497$

Namdeo AG (2007) Plant cell elicitation for production of secondary metabolites: A review. Phcog Rev 1:69-79

Park WT, Arasu MV, Al-Dhabi NA, Yeo SK, Jeon J, Park JS, Lee SY, Park SU (2016) Yeast extract and silver nitrate induce the expression of phenylpropanoid biosynthetic genes and induce the accumulation of rosmarinic acid in Agastache rugosa cell culture. Molecules 21:426

Qiao F, Chang XL, Nick P (2010) The cytoskeleton enhances gene expression in the response to the Harpin elicitor in grapevine. J Exp Bot 61:4021-4031

Rahimi S, Devi BSR, Khorolragchaa A, Kim YJ, Kim JH, Jung SK, Yang DC (2014) Effect of salicylic acid and yeast extract on the accumulation of jasmonic acid and sesquiterpenoids in Panax ginseng adventitious roots. Russ J Plant Physiol 61: 811-817

Sandeep IS, Das S, Nasim N, Mishra A, Acharya L, Joshi RK, Nayak S, Mohanty S (2017) Differential expression of CURS gene during various growth stages, climatic condition and soil nutrients in turmeric (Curcuma longa): Towards site specific cultivation for high curcumin yield. Plant Physiol Biochem 118:348-355

Wang B, Pan L, Luo J, Zha X (2009) Effect of salicylic acid on cell growth and polysaccharide production in suspension cultures 
of protocorm-like bodies from Dendrobium huoshanense. Chinese J Biotechnol 25:1062-1068

Yamamoto H, Ichimura M, Inoue K (1995) Stimulation of prenylated flavanone production by mannans and acidic polysaccharides in callus culture of Sophora flavescens.
Phytochem 40:77-81

Zhao JL, Zhou LG, Wu JY (2010) Effects of biotic and abiotic elicitors on cell growth and tanshinone accumulation in Salvia miltiorrhiza cell cultures. Appl Microbiol Biotechnol 87: 137-144 